\title{
EFEK JENIS DAGING UNGGAS YANG BERBEDA TERHADAP KUALITAS ORGANOLEPTIK ABON
}

\section{Nafly Comilo Tiven*, Marcus Veerman, Hartina Pembuain}

\author{
Jurusan Peternakan Fakultas Pertanian Universitas Pattimura \\ J1. Ir. M. Putuhena, Kampus Poka, Ambon, Kode Pos. 97233 \\ * Email: nafly tiven@yahoo.co.id
}

\begin{abstract}
ABSTRAK
Penelitian ini bertujuan untuk mengetahui pengaruh penggunaan jenis daging unggas yang berbeda terhadap kualitas organoleptik abon. Sebanyak 500 gram daging bagian dada tiga jenis unggas, yaitu ayam Arab, itik Manila dan merpati, dibuat menjadi abon. Daging direbus, disuwir, dicampur merata dengan bumbu kemudian dimasak sampai matang. Tambahkan santan, diaduk aduk dengan api yang kecil sampai santan mongering, kemudian di goreng menggunakan minyak dengan api kecil selama 10-15 menit, kemudian ditiriskan untuk menghilangkan minyak. Abon disajikan pada 3 tempat yang berbeda, kemudian diuji organoleptik (warna, aroma, tekstur, rasa dan kesukaan) menggunakan 15 orang panelis tidak terlatih. Data yang diperoleh dianalisis sidik ragam untuk rancangan acak lengkap. Hasil penelitian menunjukkan bahwa penggunaan daging unggas yang berbeda berpengaruh terhadap warna $(\mathrm{P}<0,01)$ dan tekstur $(\mathrm{P}<0,05)$ abon. Abon daging merpati cenderung berwarna coklat, dibanding abon daging ayam Arab dan itik Manila. Abon daging ayam Arab, teksturnya cenderung halus, dibanding abon daging itik Manila dan merpati. Dapat disimpulkan bahwa untuk warna, abon daging merpati lebih baik, sedangkan untuk tekstur, abon daging ayam arab lebih baik.
\end{abstract}

Kata kunci: Kualitas organoleptik, daging ayam Arab, daging itik Manila, daging merpati

\section{THE EFFECT OF DIFFERENT TYPES OF POULTRY MEAT ON ORGANOLEPTIC QUALITY OF ABON}

\begin{abstract}
This study aims was to determine the effect of different types of poultry meat on organoleptics quality of abon. As much as 500 grams of breast meat from three types of poultry (Arabian chicken, Manila duck and pigeon) are made into abon. Boiled meat, torn to lenght, mixed evenly with spices then boiled until cooked. Add the coconut milk, cooked on low fire while stirred until the coconut milk dries, then fries using oil over low fire for 10-15 minutes, then drained to remove the oil. The abon is served in 3 different places, then tested organoleptic (color, aroma, texture, taste and preference) by 15 untrained panelists. The data obtained were analyzed by variance for complete randomized design. The results showed that the use of different poultry meat had a significant on color $(\mathrm{P}<0.01)$ and texture $(\mathrm{P}<0.05)$ of abon. The abon of pigeon meat tend to be brown, compared to abon of Arabic chicken and Manila ducks. The abon of Arabic chicken meat, the texture tends to be smooth, compared to the abon of Manila duck and pigeons. It can be concluded that for color, abon of pigeon meat is better, while for texture, abon of Arabic chicken meat is better.
\end{abstract}

Key words: Organoleptic quality, Arabic chicken meat, Manila duck meat, pigeon meat

\section{PENDAHULUAN}

Dewasa ini pola konsumsi masyarakat terhadap hasil ternak (daging), cenderung bergeser, yaitu dari konsumsi daging segar menjadi konsumsi produk olahan daging siap saji. Hal ini yang mendorong perlunya inovasi teknologi untuk mengolah daging menjadi produk olahan yang sesuai dengan selera konsumen. Ini merupakan potensi dan peluang usaha yang sangat menguntungkan dan dapat dikembangkan karena ditunjang oleh tingginya pertumbuhan penduduk dan permintaan serta tingkat konsumsi masyarakat.

Salah satu produk olahan daging yang sudah dikenal masyarakat adalah abon (Jusniati et al., 2017), bahkan abon sangat digemari karena rasanya yang gurih dan cocok digunakan untuk lauk maupun di campur dengan bahan pangan lain. Menurut SNI 013707-1995, abon adalah suatu jenis makanan kering berbentuk khas, dibuat dari daging, direbus, disayat- 
Tiven, dkk. 2019: Efek Jenis Daging Unggas ....

disayat, dibumbui, digoreng dan dipres (SNI, 1995). Daging diolah menjadi abon dengan tujuan untuk menambah keanekaragaman pangan, memperoleh pangan yang berkualitas tinggi, tahan selama penyimpanan, meningkatkan nilai tukar, dan meningkatkan daya guna bahan mentahnya. Abon memiliki prospek yang sangat baik karena mudah dibuat, memiliki aroma serta rasa yang lezat dan khas, harganya relatif terjangkau, tahan lama saat penyimpanan, dapat dikembangkan sebagai salah satu usaha baik dalam skala industri kecil maupun menengah, serta prospek ekonominya yang baik karena konsumennya luas.

Kualitas abon ditentukan antara lain oleh jenis daging yang digunakan. Abon sangat sering dibuat dari daging ayam, sapi dan bahkan dari ikan. Padahal ada banyak daging, antara lain daging ungas lain, selain ayam, yang dapat dibuat menjadi abon, misalnya daging itik dan merpati. Itik merupakan ternak unggas penghasil daging yang sangat potensial di samping ayam. Kelebihan ternak ini adalah lebih tahan terhadap penyakit sehingga pemeliharaannya mudah dan relatif tidak berresiko (Budi et al., 2015). Daging itik merupakan sumber protein yang bermutu tinggi dan itik mampu berproduksi dengan baik, sehingga pengembangannya diarahkan kepada produksi yang cepat dan tinggi agar mampu memenuhi permintaan konsumen (Arsyadi dan Febrianti, 2009). Rendahnya permintaan daging itik, antara lain karena masih banyak konsumen yang belum terbiasa dengan daging itik karena aromanya yang khas, terutama yang memberi sensasi rasa dan bau (off flavor/odor) yang menyimpang yaitu bau amis/anyir (Anggraini et al., 2017). Demikian pula, warna daging itik yang lebih merah dan alot dibandingkan dengan daging ayam, semuanya ikut mempengaruhi preferensi konsumen terhadap daging itik. Jadi beberapa penyebab konsumen kurang menerima daging itik adalah warna daging, tekstur dan aroma, dimana dari ketiga penyebab tersebut, aroma merupakan penyebab yang paling dominan (Matitaputty dan Suryana, 2010). Padahal peningkatan konsumsi daging itik lokal diharapkan dapat menjadi sumber alternatif untuk mengurangi ketergantungan daging impor dari luar negeri. Upaya pengolahan daging itik diharapkan dapat meningkatkan penerimaan dan konsumsi di kalangan konsumen.

Merpati (Columba livia) merupakan komoditi ternak yang memang belum banyak peminatnya, namun mempunyai potensi besar untuk dikembangkaan, karena harganya yang relatif tinggi, masa produksi dan umur potong merpati konsumsi yang cukup mudah, membuat keuntungan didapat lebih tinggi (Samudera et al., 2016). Daging merpati memiliki kekhasan tersendiri dibandingkan dengan unggas lainnya yaitu warna daging yang merah, serat daging yang halus, kandungan protein yang tinggi dan kandungan kolesterol yang rendah serta rasa daging yang khas sehingga merupakan sajian mewah di rumah makan dan restoran (Jaelani et al., 2013). Karkas merpati belum banyak diteliti, sehingga sebagai pembanding, digunakan karkas ayam (Nurwitasari, 2006).

Sehubungan dengan itu maka akan diadakan penganekaragaman serta peningkatan produk beberapa jenis daging unggas, antara lain daging ayam Arab, daging itik Manila dan daging merpati, yang akan diolah menjadi abon. Untuk mengetahui tentang efek penggunaan jenis daging unggas yang berbeda ini terhadap kualitas abon, maka perlu diuji kualitas organoleptiknya, sehingga diharapkan dapat menjadi bahan informasi bagi seluruh stakeholder tentang kualitas sensoris abon yang diproduksi dari beberapa jenis daging unggas ini.

\section{BAHAN DAN METODE}

Bahan yang digunakan adalah daging unggas dewasa pada bagian dada, yaitu daging ayam Arab, itik Manila, dan merpati jantan dewasa, yang masingmasing diambil sebanyak 500 gram. Bumbu-bumbu, yaitu serai 20 gram, bawang putih 30 gram, bawang merah 50 gram, ketumbar 5 gram, kemiri 3 buah, garam 15 gram, gula merah 50 gram, daun salam 3 lembar, lengkuas 30 gram. Semua bumbu ini dihaluskan dan dicampur menjadi satu. Selain itu digunakan juga santan $80 \mathrm{ml}$ dan minyak goreng secukupnya.

Peralatan yang digunakan antara lain wajan sebagai wadah penggorengan, spatula dan saringan untuk penggorengan, kompor minyak, panci perebusan, blender untuk menghaluskan bumbubumbu serta timbangan digital.

Setiap daging direbus secara terpisah sampai empuk, kemudian disuwir-suwir dan dicampur merata dengan bumbu yang telah dihaluskan, kemudian dimasak hingga matang. Setelah matang, ditambahkan santan lalu diaduk-aduk diatas kompor dengan api kecil sampai mengering. Setelah masak, digoreng secara cepat $( \pm 10-15$ menit) dengan minyak dan api kecil, kemudian ditiriskan dan dipres untuk menghilangkan minyak.

Setiap sampel abon dari masing-masing unggas diletakan pada wadah yang telah disediakan. Pengujian sensoris menggunakan 20 orang panelis tidak terlatih, yang merupakan dosen dan mahasiswa Jurusan Peternakan Fakultas Pertanian Universitas Pattimura. Panelis diminta menilai warna, aroma, tekstur, rasa dan kesukaan abon sesuai skala (Tabel 1), kemudian mengisi daftar pertanyaan yang telah disediakan.

Data yang diprolehkan akan dianalisis sidik ragam untuk rancangan acak lengkap, dengan 3 perlakuan jenis daging unggas, yaitu daging ayam Arab, daging itik Manila dan daging merpati. Perbedaan antar perlakuan, diuji lanjut menggunakan Uji Duncan (Oramahi, 2008). 
Tabel 1. Skala uji sensoris abon beberapa daging unggas

\begin{tabular}{ccl}
\hline \hline Variabel & Skala & \\
\hline Warna & 3 & Kriteria Abon \\
& 2 & Coklat kekuningan \\
& 1 & Coklat pucat \\
\hline Aroma & 3 & Kuat aroma daging \\
& 2 & Sedang aroma daging \\
& 1 & Lemah aroma daging \\
\hline Tekstur & 3 & Sangat Halus \\
& 2 & Halus \\
& 1 & Tidak halus \\
\hline Rasa & 3 & Kuat rasa daging \\
& 2 & Sedang rasa daging \\
& 1 & Lemah rasa daging \\
\hline Kesukaan & 3 & Sangat disukai \\
& 2 & Disukai \\
& 1 & Tidak disukai \\
\hline
\end{tabular}

HASIL DAN PEMBAHASAN

\section{Warna Abon}

Pengaruh penggunaan daging unggas yang berbeda terhadap warna abon, dapat dilihat pada Gambar 1 di bawah ini.

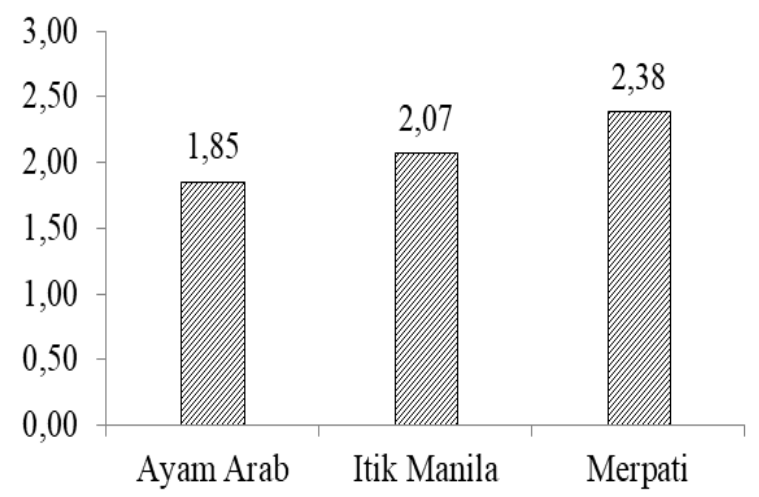

Gambar 1. Pengaruh penggunaan daging unggas yang berbeda terhadap warna abon.

Hasil analisis statistik menunjukkan bahwa penggunaan daging unggas yang berbeda berpengaruh sangat nyata $(\mathrm{P}<0,01)$ terhadap warna abon. Skor warna abon tertinggi terdapat pada abon yang menggunakan daging merpati, yang cenderung berwarna coklat, sedangkan skor warna abon terendah terdapat pada abon yang menggunakan daging ayam Arab, yang berwana coklat pucat cenderung coklat kekuningan. Dengan demikian abon merpati memiliki nilai warna lebih baik dibandingkan abon daging ayam Arab dan itik Manila.

Perbedaan nilai warna abon dari ketiga jenis daging disebabkan oleh reaksi pencoklatan akibat pemasakan. Penyebab warna coklat pada abon adalah karbohidrat akibat penambahan gula pada saat pembuatan abon. Pada saat suhu tinggi akibat pemasakan, akan terjadi reaksi Maillard, yaitu reaksi pencoklatan non enzimatis akibat reaksi antara protein pada daging dan gula-gula pereduksi (Muchtadi, 2008). Warna coklat terbentuk karena adanya kadar air yang rendah, suhu tinggi, jenis asam amino dan cahaya. Bahan makanan telah mengalami perubahan oleh panas, dapat diduga berubah pula kemampuan untuk memantulkan atau meneruskan cahaya.

Selain itu warna coklat ini juga dipengaruhi oleh warna masing-masing jenis daging, dimana daging merpati muda (squab/piyik) mempunyai warna merah serta mengandung kolesterol yang rendah (Nurwitasari, 2006). Diduga, daging merpati yang digunakan lebih merah tua, akibat umur yang lebih tua, menyebabkan pada saat dimasak abon akan menjadi coklat. Selain itu akibat kolesterol yang rendah menyebabkan abon daging merpati tidak terlalu berwarna coklat kekuningan, tetapi cenderung coklat.

\section{Aroma Abon}

Hasil analisis statistik menunjukkan bahwa penggunaan daging unggas yang berbeda berpengaruh tidak nyata terhadap aroma abon. Bila dilihat dari skor aroma, maka skor aroma abon tertinggi terdapat pada abon yang menggunakan daging itik Manila. 
sedangkan skor warna abon terendah terdapat pada abon yang menggunakan daging merpati (Gambar 2).

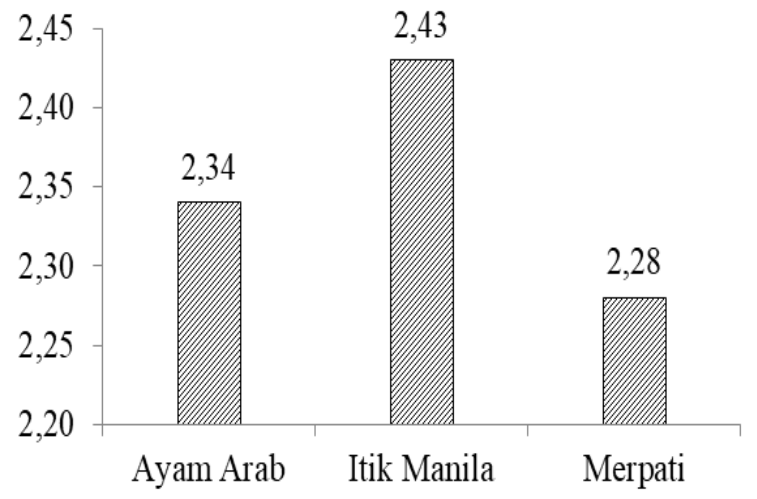

Gambar 2. Pengaruh penggunaan daging unggas yang berbeda terhadap aroma abon

Skor aroma abon ini lebih dipengaruhi oleh aroma khas masing-masing jenis daging serta bumbubumbu atau bahan-bahan yang ditambahkan dalam proses pembuatan abon. Menurut Matitaputty dan Suryana (2010), daging itik mengandung aromanya yang khas, terutama yang memberi sensasi rasa dan bau (off flavor/odor) yang menyimpang yaitu bau amis/anyir. Konsumen kurang menerima daging itik karena aroma/baunya yang sangat dominan. Kombinasi gula, garam dan bumbu-bumbu menimbulkan bau yang khas pada produk akhir (Purnomo, 2012).

Aroma abon juga dipengaruhi oleh penambahan bumbu-bumbu yang memiliki minyak atsiri yang mudah menguap, sehingga pada saat diolah akan mengeluarkan aroma yang khas. Aroma ini juga bisa dipengaruhi oleh minyak, dimana pada saat penggorengan akan terbentuk senyawa tertentu pada minyak dan hasil gorengan, akibat naiknya suhu dan lama penggorengan. Menurut Muchtadi (2008), selama proses penggorengan terjadi perubahan fisik, kimia dan sifat sensoris.

\section{Tekstur Abon}

Pengaruh penggunaan daging unggas yang berbeda terhadap tekstur abon, dapat dilihat pada Gambar 3. Hasil analisis statistik menunjukkan bahwa penggunaan daging unggas yang berbeda berpengaruh nyata $(\mathrm{P}<0,05)$ terhadap tekstur abon. Skor tekstur abon tertinggi terdapat pada abon yang menggunakan daging ayam Arab, sedangkan skor tektur abon terendah terdapat pada abon yang menggunakan daging itik Manila. Dengan demikian walaupun skor tekstur abon ketiga jenis unggas ini berkisar pada skor 1 (tidak halus), tetapi abon daging ayam Arab mempunyai tekstur yang cenderung halus.

Tekstur abon ini sangat dipengaruhi oleh serat masing-masing daging. Diduga serat daging ayam Arab, seperti daging ayam pada umumnya, lebih halus dibanding serat daging itik Manila dan merpati.
Menurut Rakhmawati et al. (2016), daging dada pada ayam memiliki serat daging yang halus dan panjang, diantara serat tidak terdapat simpanan lemak berwarna putih kekuningan dan kulit licin dan berlemak. Hal ini yang membuat panelis lebih menyukai abon daging ayam Arab. Serabut otot itik betina tua mempunyai diameter yang lebih besar dibandingkan dengan serabut otot entog, baik pada bagian otot dada maupun paha (Suryaningsih, 2012). Besar kecilnya diameter serabut otot mempengaruhi tekstur dan keempukan daging (Dwiastari, 2009).

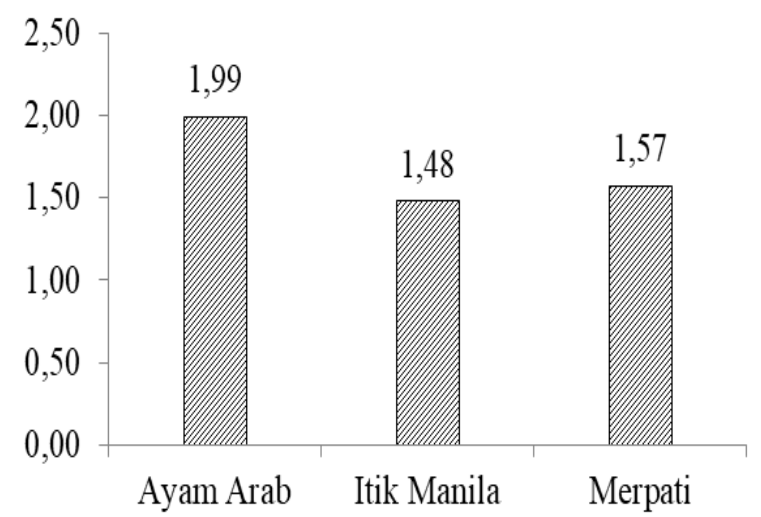

Gambar 3. Pengaruh penggunaan daging unggas yang berbeda terhadap tekstur abon

\section{Rasa Abon}

Pengaruh penggunaan daging unggas yang berbeda terhadap rasa abon, dapat dilihat pada Gambar 4. Hasil analisis statistik menunjukkan bahwa penggunaan daging unggas yang berbeda berpengaruh tidak nyata terhadap rasa abon. Walaupun tidak berbeda, tetapi bila dilihat dari skor nilai rasa abon, maka rasa abon tertinggi terdapat pada abon yang menggunakan daging merpati, sedangkan skor rasa abon terendah terdapat pada abon yang menggunakan daging ayam Arab.

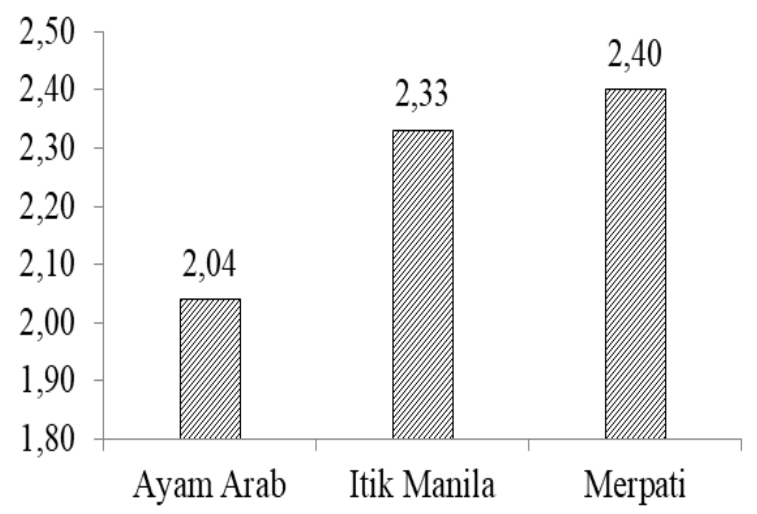

Gambar 4. Pengaruh penggunaan daging unggas yang berbeda terhadap rasa abon

Rasa merupakan salah satu atribut mutu yang menentukan dalam penerimaan konsumen terhadap 
suatu produk. Rasa abon dalam penelitian ini lebih banyak ditentukan oleh jenis daging yang digunakan. Menurut Jaelani et al. (2013), daging merpati mempunyai rasa yang khas, serta kandungan kolesterol yang rendah. Selain itu daging merpati juga memiliki serat daging yang halus serta kandungan protein yang tinggi.

\section{Kesukaan Abon}

Pengaruh penggunaan daging unggas yang berbeda terhadap kesukaan abon, dapat dilihat pada Gambar 5 di bawah ini.

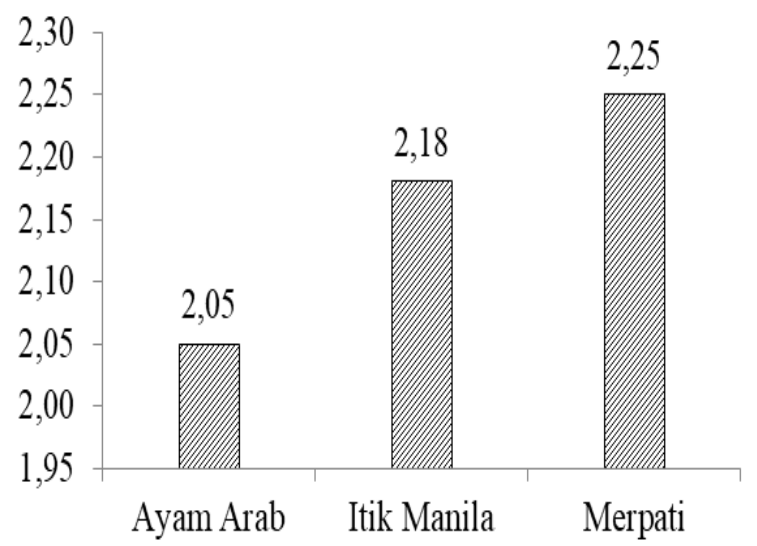

Gambar 5. Pengaruh penggunaan daging unggas yang berbeda terhadap kesukaan abon

Hasil analisis statistik menunjukkan bahwa penggunaan daging unggas yang berbeda berpengaruh tidak nyata terhadap kesukaan abon. Walaupun tidak berbeda, tetapi bila dilihat dari skor nilai kesukaan, maka abon dengan kesukaan tertinggi terdapat pada abon yang menggunakan daging merpati, sedangkan abon dengan kesukaan terendah terdapat pada abon yang menggunakan daging ayam Arab.

Panelis lebih menyukai abon daging merpati, mungkin disebabkan karena warna dan dan rasa daging merpati yang lebih baik dibanding abon daging ayam Arab dan itik Manila. Menurut Suryaningsih et al. (2012) dan Aberle et al. (2001), warna, rasa, bau sangat berperan dalam mempengaruhi pemilihan dan kesukaan konsumen akan makanan, sehingga tidak mengherankan jika banyak bahan pangan yang mempunyai warna, rasa, bau yang kurang disukai pada akhirnya tidak dipilih oleh konsumen.

\section{SIMPULAN}

Berdasarkan hasil penelitian dapat disimpulkan bahwa abon yang dibuat dari daging ayam Arab, itik Manila dan merpati mempunyai kualitas organoleptik yang berbeda pada warna dan tekstur, yaitu :

1. Abon yang menggunakan daging merpati mempunyai warna yang lebih baik, yaitu cenderung coklat, dibanding abon yang menggunakan daging ayam Arab dan daging itik Manila.
2. Abon yang menggunakan daging ayam Arab mempunyai tekstur yang lebih halus, dibanding abon yang menggunakan daging itik manila dan daging merpati.

\section{DAFTAR PUSTAKA}

Aberle E. D., J. C. Forrest, D. E. Gerrand and E. W. Mills. 2001. Principles of Meat Science. Fourth Edition. USA: Kendal/Hunt Publishing Company.

Anggraini, P. N., S. Susanti, dan V. P. Bintoro. 2017. Karakteristik Fisikokimia dan Organoleptik Bakso Itik dengan Tepung Porang sebagai Pengenyal. Jurnal Teknologi Pangan. 3(1): 155-160.

Arsyadi, A. dan N. Febrianti. 2009. Performans Itik Pedaging (Lokal X Peking) Fase Starter Pada Tingkat Kepadatan Kandang yang Berbeda Di Desa Laboi Jaya Kabupaten Kampar. Jurnal Peternakan. 6(1): 29-35.

Budi, E. S., E. Yektiningsih, dan E. Priyanto. 2015. Profitabilitas Usaha Ternak Itik Petelur Di Desa Kebonsari Kecamatan Candi, Sidoarjo. Jurnal Agraris. (1): 32-37.

Dewiastari. 2009. Perendaman Daging Paha Itik Lokal dalam sari Buah Nenas. https://dewiastari. wordpress.com/2009/12/22/hello-world/. [11/03/2019].

Jaelani, A, N. Widaningsih dan A. Sarifli. 2013. Kadar Kolesterol Dan Perecahan Karkas Merpati Lokal Yang Dipotong Pada Umur Berbeda. J. Agroscientiae. 20(3): 103-109.

Jusniati, Patang, dan Kadirman. 2017. Pembuatan Abon Dari Jantung Pisang (musa paradisiaca) Dengan Penambahan Ikan Tongkol (Euthynnus affinis). Jurnal Pendidikan Teknologi Pertanian. 3 : 58-66.

Matitaputty, P. R dan Suryana. 2010. Karakteristik Daging Itik Dan Permasalahan Serta Upaya Pencegahan Off-Flavor Akibat Oksidasi Lipida. J. Wartazoa. 20(3): 130-138.

Muchtadi, T. R. 2008. Teknologi Proses Pengolahan Pangan. Third Edition. Bogor: Institut Pertanian Bogor.

Nurwitasari, W. 2006. Nilai Gizi Daging Squab Burung Merpati Lokal dan Homer Pada Jenis Kelamin yang Berbeda. [Skripsi]. Bogor: Program Studi Teknologi Hasil Ternak Institut Pertanian Bogor.

Oramahi, H. A. 2008. Analisis data dengan SPSS \& SAS. Studi Kasus Bidang Pertanian, Kehutanan Dan Peternakan. Yogyakarta: Ardana Media. 
Purnomo, H. 2012. Teknologi Pengolahan dan Pengawetan Daging. Malang: Universitas Brawijaya Press.

Rakhmawati, R,, M. Sulistyoningsih dan A.N. Puteri. 2016. Pengaruh Jenis Ayam Terhadap Uji Organoleptik Pada Dendeng Ayam. Prosiding. Seminar Nasional Hasil Penelitian 2016 Lembaga Penelitian dan Pengabdian Kepada Masyarakat Universitas PGRI Semarang Sabtu, 22 Oktober 2016. p. 125-131.

SNI. 1995. Standar Nasional Indonesia. Abon. SNI 013707-1995. Badan Standardisasi Nasional.
Samudera, R., S. Dharmawati dan S. Prasetiyo. 2016. Kadar Lemak dan Protein Daging Burung Merpati Lokal (Columba Livia) yang Dipelihara Secara Intensif dan Dipotong pada Umur Berbeda. J. Al Ulum Sains dan Teknologi. 2(1): 6-9.

Suryaningsih, L., W. S. Putranto dan E. Wulandari. 2012. Pengaruh Perendaman Daging Itik Pada Berbagai Konsentrasi Ekstrak Kunyit (Curcuma Domestika) Terhadap Warna, Rasa, Bau, dan pH. Jurnal Ilmu Ternak. 12(1): 24-28.

Available online at journal homepage: http://ojs3.unpatti.ac.id/index.php/agrinimal 